\title{
Silencing of ATP synthase $\beta$ reduces phytoplasma multiplication in the leafhopper vector Euscelidius variegatus
}

\section{Luciana Galetto ${ }^{1}$, Simona Abbà ${ }^{1}$, Marika Rossi ${ }^{1}$, Matteo Ripamonti ${ }^{1,2}$, Sabrina} Palmano ${ }^{1}$, Domenico Bosco ${ }^{1,2, *}$, and Cristina Marzachì ${ }^{1}$

1 Istituto per la Protezione Sostenibile delle Piante, Consiglio Nazionale delle Ricerche, IPSP-CNR, Strada delle Cacce 73 10135, Torino, Italy;

2 Dipartimento di Scienze Agrarie, Forestali ed Alimentari DISAFA, Università degli Studi di Torino, Largo Paolo Braccini 2, 10095, Grugliasco (TO), Italy;

luciana.galetto@ipsp.cnr.it

simona.abba@ipsp.cnr.it

marika.rossi@ipsp.cnr.it

matteo.ripamonti@unito.it

sabrina.palmano@ipsp.cnr.it

cristina.marzachi@ipsp.cnr.it

* Correspondence: domenico.bosco@unito.it 


\begin{abstract}
The leafhopper Euscelidius variegatus is a natural vector of the chrysanthemum yellows phytoplasma ( $\mathrm{CYp}$ ) and a laboratory vector of the Flavescence dorée phytoplasma (FDp). Previous studies indicated a crucial role for insect ATP synthase $\alpha$ and $\beta$ subunits during phytoplasma infection of the vector species. Gene silencing of ATP synthase $\beta$ was obtained by injection of specific dsRNAs in $E$. variegatus. Here we present the systemic and long-lasting nature of such silencing, its effects on the small RNA profile, the significant reduction of the corresponding protein expression, and the impact on phytoplasma acquisition capability. The specific transcript expression was silenced at least up to 37 days post injection with an average reduction of 100 times in insects injected with dsRNAs targeting ATP synthase $\beta$ (dsATP) compared with those injected with dsRNAs targeting green fluorescent protein (dsGFP), used as negative controls. Insects injected either with dsATP or dsGFP successfully acquired CYp and FDp during feeding on infected plants. However, the average phytoplasma amount in dsATP insects was significantly lower than that measured in dsGFP specimens, indicating a probable reduction of the pathogen multiplication rate when ATP synthase $\beta$ was silenced. The role of the insect ATP synthase $\beta$ during phytoplasma infection process is discussed.
\end{abstract}

Keywords RNA interference; small RNAs; Flavescence dorée phytoplasma; 'Candidatus Phytoplasma asteris'

\title{
1. Introduction
}

Phytoplasmas are plant pathogenic bacteria associated with diseases that cause severe economic impacts on many crops worldwide (Tomkins et al., 2018). These Mollicutes are currently classified within the provisional genus 'Candidatus Phytoplasma' (Marcone, 2014). They are transmitted by phloem feeding hemipteran insects (leafhoppers, planthoppers, and psyllids) in a persistent propagative manner (Bosco and Marzachi, 2016). Phytoplasmas are obligate parasites that live and multiply in close association with their hosts: in plants they inhabit phloem elements (Marcone, 2014), in insects they enter the anterior midgut and colonize salivary glands to be re-transmitted (Koinuma et al., 2020). Control strategies to counteract phytoplasma diseases are mainly based on removal of infected plants and insecticide treatments against vectors, with undesired side effects on environment and public health (Jarausch and Torres, 2014). Moreover, the unculturable nature of these pathogens hampered the studies of their basic biology and their pathogenicity mechanisms. In such a scenario, RNA interference (RNAi) could be exploited as a useful tool for species-specific vector suppression (Taning et al., 2020; Zhu and Palli, 
2020; Zotti et al., 2018). Moreover, this technique allows identification of insect gene function with regard to interactions with phytoplasmas for transmission.

RNAi is a sequence-specific mechanism of eukaryotes, that regulates gene expression and provides a natural defence against nucleic acids of transposons or viruses (Taning et al., 2020). As a molecular tool, RNAi allows specific posttranscriptional silencing of target genes, and is a powerful tool for understanding gene function and regulation (Zotti et al., 2018). RNAi efficiency varies among insect orders (being Lepidoptera, Diptera, Hymenoptera, and Hemiptera the most studied ones), and also within species in the same order (Zhu and Palli, 2020). Many uncertainties remain on RNAi mechanisms occurring in insects, especially in nonmodel species, although RNAi has been reported for several hemipteran virus vectors (Chen et al., 2015; Kanakala and Ghanim, 2016; Matsumoto and Hattori, 2016; Xue et al., 2020) as well as for the phytoplasma vector Euscelidius variegatus Kirschbaum (Hemiptera: Cicadellidae (Abbà et al., 2019).

Euscelidius variegatus is a natural vector of chrysanthemum yellows (CYp) isolate of the 'Candidatus Phytoplasma asteris', and an efficient vector of Flavescence dorée phytoplasma (FDp) under laboratory conditions (Galetto et al., 2018). 'Candidatus Phytoplasma asteris' includes isolates associated with over 100 economically relevant plant diseases worldwide and is the most diverse and widespread phytoplasma group (Lee, 2004). The CYp isolate is associated with a disease of ornamental plants in Northwestern Italy (Conti et al., 1988). Flavescence dorée phytoplasma is a quarantine pest and causes an economically important grapevine disease representing one of the major threats to southern European viticulture (EFSA Panel on Plant Health PLH, 2014). Under field conditions, E. variegatus, Macrosteles quadripunctulatus Kirschbaum, and Euscelis incisus Kirschbaum are efficient vectors of CYp (Bosco et al., 2007; Conti et al., 1988), whereas FDp is transmitted to grapevine by Scaphoideus titanus Ball (EFSA Panel on Plant Health PLH, 2014). Compulsory insecticide treatments against the latter species as well as roguing of infected grapevines and their replacement with new grafted cuttings are the main preventive strategies to control the disease (EFSA Panel on Plant Health PLH et al., 2016). There is urgent demand for new and more sustainable management strategies to cope with economically important phytoplasma diseases such as FD. For this purpose, knowledge gaps on mechanisms exploited by phytoplasmas to colonize vectors must be filled. A laboratory model has been established to manage the FDp infection cycle using the herbaceous Vicia faba as host plant and the polivoltine leafhopper E. variegatus as laboratory vector (Caudwell et al., 1972), thus overcoming difficulties in dealing with a woody host (grapevine) and a monovoltine vector ( $S$. titanus).

Phytoplasmas lack cell walls and therefore proteins exposed on the pathogen membrane are in direct contact with the host proteins. Several lines of evidence indicate that phytoplasma membrane proteins are crucial during the infection process of either plant or insect hosts, as reviewed in (Rossi et al., 2019). In particular, previous studies demonstrated that actin and ATP synthase $\alpha / \beta$ subunits of different 
insect vectors interact in vitro with the phytoplasma Antigenic membrane protein (Amp) of 'Ca. P. asteris', which is required for pathogen transmission in vivo (Galetto et al., 2011; Rashidi et al., 2015; Suzuki et al., 2006). RNAi has been successfully applied to silence muscle actin and ATP synthase $\beta$ genes of E. variegatus, following abdominal microinjection of dsRNAs (Abbà et al., 2019). The latter protein is part of the $\mathrm{F}_{1}-\mathrm{F}_{0}$ ATP synthase complex, a large multi-subunit mitochondrial enzyme that uses the proton gradient generated by the respiratory chain to synthesize ATP, whose general structure is highly conserved throughout evolution (Leyva et al., 2003).

The present work aims at characterizing gene silencing in E. variegatus, its systemic spread in the insect body, duration, small RNA (sRNA) profile and effects on the corresponding protein level. Moreover, we demonstrate that vector ATP synthase $\beta$ silencing suppresses phytoplasma multiplication, a further proof of the functional role of this gene in the phytoplasma infection of the insect.

\section{Materials and Methods}

\subsection{Insect rearing and phytoplasma isolates}

Euscelidius variegatus were originally collected in Piedmont region of Italy and continuously reared on oat, Avena sativa (L.), inside plastic and nylon cages in growth chambers at $20-25{ }^{\circ} \mathrm{C}$ with a L16:D8 photoperiod (Rashidi et al., 2014). To obtain same age E. variegatus adults, about two weeks before the experiments, the required amount of $4^{\text {th }}$ and $5^{\text {th }}$ instar nymphs were taken from the main rearing and caged altogether on oats. Newly emerged adults were then injected with dsRNAs.

Chrysanthemum yellows phytoplasma (CYp, 16SrI-B), belonging to the 'Candidatus Phytoplasma asteris' species, was isolated in the Italian Riviera (Liguria region) and maintained by insect transmission on daisy, Chrysanthemum carinatum Schousboe (Rashidi et al., 2014). Flavescence dorée phytoplasma (FDp, 16SrV-C) was identified in a vineyard of the Piedmont region of Italy, and transmitted to broad bean, Vicia faba L., by the natural vector S. titanus previously fed on infected grapevines; FDp was then maintained on broad bean by insect transmission, using the laboratory vector E. variegatus (Galetto et al., 2014). Daisies, broad beans, and oats were all grown from seed in greenhouses. For each acquisition access period (AAP), the sanitary status of source plants was confirmed by symptom observation and PCR diagnosis as previously described (Rashidi et al., 2014).

\subsection{Synthesis and delivery of dsRNAs}

The complete coding sequence of E. variegatus ATP synthase $\beta$ (target mRNA) used in this work can be found in the TSA sequence database (BioProject: PRJNA393620) at NCBI under the accession number GFTU01013594.1 (Galetto et al., 2018).

The molecules of dsRNAs targeting E. variegatus ATP synthase $\beta$ (dsATP) and the gene sequence of the green fluorescent protein (dsGFP), used as negative control, were synthetized as detailed in (Abbà et al., 2019). Briefly, plasmids harbouring 
target sequences under T7 promoter regulation were in vitro transcribed with MEGAscript RNAi Kit (Thermo Fisher Scientific), purified with ssDNA/RNA Clean and Concentrator (Zymo Research), eluted in Tris-EDTA buffer (10mM Tris- $\mathrm{HCl}$, 0.1mM EDTA, pH 8.5) and quantified with a Nanodrop ND-1000 spectrophotometer (Thermo Fisher Scientific).

Newly-emerged adults were anaesthetized with $\mathrm{CO}_{2}$ and microinjected between two abdominal segments under a stereomicroscope using a fine glass needle connected to a Cell Tram Oil microinjector (Eppendorf). Insects were microinjected with $0.5 \mu \mathrm{L}$ of dsRNAs at the concentration of $160 \mathrm{ng} \mu \mathrm{L}^{-1}$. Groups of injected insects were then caged on oat plants and monitored daily until the end of the experiments. Dead insects were removed periodically.

\subsection{RNA extraction, $c D N A$ synthesis, and gene expression analysis}

Total RNAs were extracted from single E. variegatus adult (separated head and body or whole insect) at different times after dsRNA injection. The samples were frozen with liquid nitrogen, crushed with a micropestle in sterile Eppendorf tubes, and homogenized in $0.5 \mathrm{~mL}$ Tri-Reagent (Zymo Research). Samples were centrifuged $1 \mathrm{~min}$ at $12000 \mathrm{~g}$ at $4^{\circ} \mathrm{C}$ and RNAs were extracted from supernatants with Direct-zol RNA Mini Prep kit (Zymo Research), following manufacturer's protocol and including the optional DNAse treatment step. Concentration, purity, and quality of extracted RNA samples were analysed in a Nanodrop ND-1000 spectrophotometer (Thermo Fisher Scientific).

Quantitative RT-PCR (qRT-PCR) was used to quantify the ability of the injected dsRNAs to knockdown target mRNA (ATP synthase $\beta$ ) in insects collected at 15, 22 and 37 days post injection (dpi), analysed as whole body (22 and $37 \mathrm{dpi}$ ) or as separated head and body (15 dpi). For each sample category, at least 10 biological replicates with balanced sex ratio were analysed to compare levels of ATP synthase $\beta$ transcript between insects injected with dsATP and dsGFP. For each sample, cDNA was synthesized from total RNA $(1 \mu \mathrm{g})$ with random hexamers using a High Capacity cDNA reverse transcription kit (Applied Biosystems). The resulting cDNA was used as a template for $\mathrm{qPCR}$ in a $10 \mu \mathrm{L}$ volume mix, containing $1 \times$ iTaq Universal Sybr Green Supermix (Bio-Rad) and $300 \mathrm{nM}$ of each primer. All primer pairs used in this work are listed in Supplementary Table S1. Samples were run in duplicate in a CFX Connect Real-Time PCR Detection System (Bio-Rad). Cycling conditions were: $95^{\circ} \mathrm{C}$ for $3 \mathrm{~min}$, and 40 cycles at $95^{\circ} \mathrm{C}$ for $15 \mathrm{~s}$ and $60{ }^{\circ} \mathrm{C}$ for $30 \mathrm{~s}$ of annealing/extension step. The specificity of the PCR products was verified by melting curve analysis for all samples. No-template and no-reverse transcribed controls were always included in each plate. Primers targeting glutathione Stransferase and elongation factor- $1 \alpha$ were used as internal controls to normalize the cDNA among samples. Normalized expression levels of each target gene for each sample were calculated by CFXMaestro ${ }^{\mathrm{TM}}$ Software (Bio-Rad). As no significant gender-based differences were observed, male and female samples were pooled together. 
In order to check for the presence of the whole dsGFP sequence in dsGFPinjected insects at $22 \mathrm{dpi}$, cDNA was synthesized from total RNA (200 ng) using the High Capacity cDNA reverse transcription kit (Thermo Fisher Scientific Inc., MA, USA). Qualitative RT-PCR was conducted with the same primers used for the dsGFP synthesis without the T7 tail (Supplementary Table S1).

\subsection{Library construction, sequencing, and bioinformatic analyses of small RNAs}

Total RNAs extracted from whole insect bodies sampled on the $22^{\text {nd }}$ day after the injection of either dsATP or dsGFP were sent to Macrogen Inc. (South Korea) for small RNA (sRNA) library construction and sequencing. Three biological replicates were prepared for each condition, each containing a pool of six individuals: Eva_ATP1, Eva_ATP2 and Eva_ATP3 libraries for insects injected with dsATP and Eva_GFP1, Eva_GFP2 and Eva_GFP3 libraries for insects injected with dsGFP. Briefly, libraries were prepared with the Illumina TruSeq Small RNA Library construction kit (Illumina Inc., San Diego, CA, USA) and sequenced by the Illumina HiSeq2500 in rapid run mode 1x50bp. Raw reads were trimmed from adapters with Cutadapt, version 1.18 (Martin, 2011), and filtered out according to a) quality and length (minimum $16 \mathrm{nt}$; maximum $30 \mathrm{nt}$ ) with Reformat, version 37.71 (part of BBMap suite) (Bushnell, 2014) and b) mapping onto the E. variegatus ATP synthase $\beta$ sequence. Bowtie version 1.1.2 software (Langmead, 2010) with no mismatch allowed in the alignment was used to establish sRNA abundance profiles of the six sequenced samples. Following alignment, the resulting SAM files were converted to BAM format, sorted by position and indexed using SAMtools version 1.9 (Li et al., 2009) and visualized with the Integrative Genomics Viewer (IGV) (Robinson et al., 2017). sRNA counts were normalized for differences in sequencing depths to account for the technical differences across samples.

\subsection{Western blots}

This procedure was used to quantify the expression of the ATP synthase $\beta$ protein, in E. variegatus specimens collected at 4, 6, 8, 12 and 15 days post injection (dpi) of silencing dsRNAs. At each sampling date, and for each group of insects (dsATP vs. dsGFP), four to six insect samples were singly analyzed. Single insects were homogenized in $1.5 \mathrm{~mL}$ tube with micro-pestle in $100 \mu \mathrm{L}$ of Rx Buffer $(0.1 \%$ Triton X-100, $100 \mathrm{mM} \mathrm{KCl}, 3 \mathrm{mM} \mathrm{NaCl}, 3.5 \mathrm{mM} \mathrm{MgCl}$, $1.25 \mathrm{mM}$ EGTA, and $10 \mathrm{mM}$ Hepes, pH 7.3) (Suzuki et al., 2006), sonicated for $1 \mathrm{~min}$ at RT and centrifuged for 1 $\mathrm{min}$ at $13000 \mathrm{~g}$. The supernatant was recovered and an aliquot was quantified in a UV-vis spectophotometer with Bradford reagent (Bio-Rad) along with a standard curve of known dilutions of Bovine Serum Albumin (BSA) dissolved in Rx Buffer. For each sample, $1 \mu \mathrm{g}$ of total proteins was loaded onto $12 \%$ polyacrylamide gel, together with $3 \mu \mathrm{L}$ of Sharpmass VI Prestained Protein Marker (EuroClone) and 5 $\mu \mathrm{L}$ of Unstained SDS-PAGE Standards, broad range (Bio-Rad). Gels were either stained with colloidal Coomassie stain (Candiano et al., 2004) or blotted on a polyvinylidene difluoride (PVDF) membrane. Membranes were blocked for $30 \mathrm{~min}$ with 3\% BSA dissolved in Tris-buffered saline with $0.1 \%$ Tween (BSA-TBST) and 
incubated overnight at $4{ }^{\circ} \mathrm{C}$ with primary antibody (ab43177 chicken-developed anti-ATP synthase $\beta$, Abcam plc) diluted 1:5000 in BSA-TBST. Blots were then washed four times with BSA-TBST, incubated for $2 \mathrm{~h}$ with horseradish peroxidase (HRP)-conjugated secondary antibody (12-341 Rabbit anti-chicken RAC-HRP, Sigma-Aldrich) diluted 1:15000 in BSA-TBST, washed four times with TBST, and developed with West Pico SuperSignal chemiluminescent substrate (Pierce) in a VersaDoc 4000 MP system (Bio-Rad).

Quantity One 1-D Analysis Software (Bio-Rad) was used to estimate band intensities of each sample, expressed as intensity $/ \mathrm{mm}^{2}$.

\subsection{Phytoplasma acquisition, detection, and quantification}

Following injection of dsRNAs (targeting either GFP as a control or ATP synthase $\beta$ ), insects were allowed to acquire phytoplasma by feeding on infected plants for few days (two and four days of acquisition access period, AAP, for CYp and FDp, respectively), then isolated on oat plants for a short latency (five and three days for CYp and FDp, respectively), and thus collected for molecular analyses at seven days post acquisition (dpa), as depicted in Figure 1.

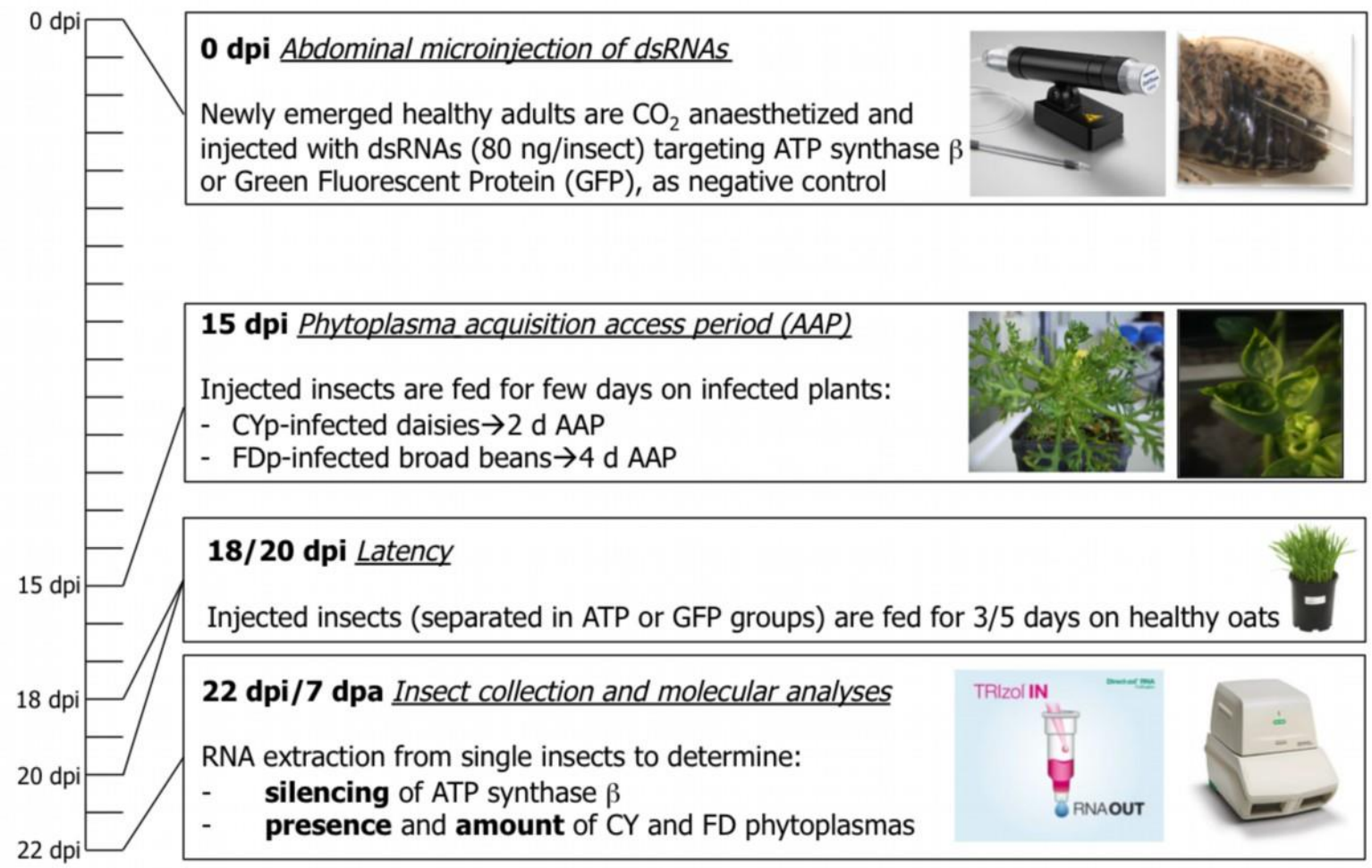

Figure 1. Methodology of phytoplasma acquisition experiments. dpi: days post injection; dpa: days post acquisition.

A multiplex quantitative RT-PCR (qRT-PCR) was used to detect phytoplasma presence and measure pathogen load in insects injected with dsATP or dsGFP. About 40 biological replicates were analysed for each dsRNA-injected group. Universal phytoplasma primers CYS2Fw/Rv and FAM-labelled TaqMan CYS2Probe designed on ribosomal 16SrRNA gene sequence were used to detect CYp or FDp 
(Marzachí and Bosco, 2005). Primers GapFw632/GapRv819 and HEX-labelled TaqMan GapEvProbe were used to measure E. variegatus glyceraldehyde-3phosphate dehydrogenase (GAPDH) transcript, chosen as endogenous normalization control (Ottati et al., 2020). The sequences of primers and probes are detailed in Supplementary Table S1. For each sample, cDNA was synthesized as described above and one $\mu \mathrm{L}$ was used as template in a multiplex reaction mix of 10 $\mu \mathrm{L}$ total volume, containing 1x iTaq Universal Probes Supermix (Bio-Rad), $300 \mathrm{nM}$ of each of the four primers and $200 \mathrm{nM}$ of each of the two TaqMan probes. Each sample was run in triplicate in a CFX Connect Real-Time PCR Detection System (BioRad). Cycling conditions were $95^{\circ} \mathrm{C}$ for $3 \mathrm{~min}$ and 40 consecutive cycles at $95^{\circ} \mathrm{C}$ for $10 \mathrm{~s}$ as denaturing step followed by $30 \mathrm{~s}$ at $60^{\circ} \mathrm{C}$ as annealing/extension step. In each qPCR plate, four serial 100-fold dilutions of pGem-T Easy (Promega) plasmids, harbouring the target phytoplasma and insect genes, were included for relative quantification of the pathogen loads. For both plasmid standard curves, dilutions included in plates ranged from $10^{8}$ to $10^{2}$ target copy numbers per $\mu \mathrm{L}$. Dilution series of both plasmids were used to calculate qPCR parameters (reaction efficiency and $\mathrm{R}^{2}$ ). Mean copy number of phytoplasma ribosomal transcripts were used to express pathogen amount as CYp or FDp 16SrRNA/insect GAPDH transcript. The experiment was repeated twice for each phytoplasma species.

\subsection{Statistical analyses}

SigmaPlot version 13 (Systat Software, Inc., www.systatsoftware.com.) was used for statistical analyses. Kruskal Wallis test, followed by Dunn's method as pairwise multiple comparison procedure, was used to compare ATP synthase $\beta$ transcript levels measured in heads or bodies of insects injected with dsGFP or dsATP. MannWhitney rank sum test was used to compare mean levels of ATP synthase $\beta$ transcripts measured in insects injected with dsGFP or dsATP as well as to compare the mean phytoplasma loads quantified in the same insect groups. To compare pixel intensities in WB images between insects injected with dsGFP or dsATP t-test was used.

\section{Results}

\subsection{Silencing of ATP synthase $\beta$ is systemic and long-lasting}

Abdominal microinjection of ATP synthase $\beta$ dsRNAs into E. variegatus adults caused a significant strong decrease in the expression of the target gene, with a reduction ranging from 50 to over 130 times in comparison with the corresponding dsGFP-treated controls, according to the different experiments (Figure 2 and Supplementary Table S2). At 15 days post injection (dpi) silencing of the target was recorded both at the injection site (abdomen) and in the head, indicating systemic diffusion of the silencing signals. Indeed, significant reduction of ATP synthase $\beta$ transcription was observed both in dissected heads and abdomens of insects injected with dsATP in comparison with those of insects injected with dsGFP (Figure 2a; Kruskal-Wallis, H=29.545, $\mathrm{P}<0.001$, Dunn's Method). 
Transcriptional silencing also showed long-lasting effects, as ATP synthase $\beta$ transcript levels remained significantly lower in insects injected with dsATP than in those treated with dsGFP, at least up to $37 \mathrm{dpi}$ (Figure $2 \mathrm{~b}$ and $\mathrm{c}$; Mann-Whitney, $\mathrm{U}=0.000, \mathrm{~T}=10428, \mathrm{P}<0.001$ at $22 \mathrm{dpi}$ and $\mathrm{U}=0.000, \mathrm{~T}=105, \mathrm{P}<0.001$ at $37 \mathrm{dpi}$ ).
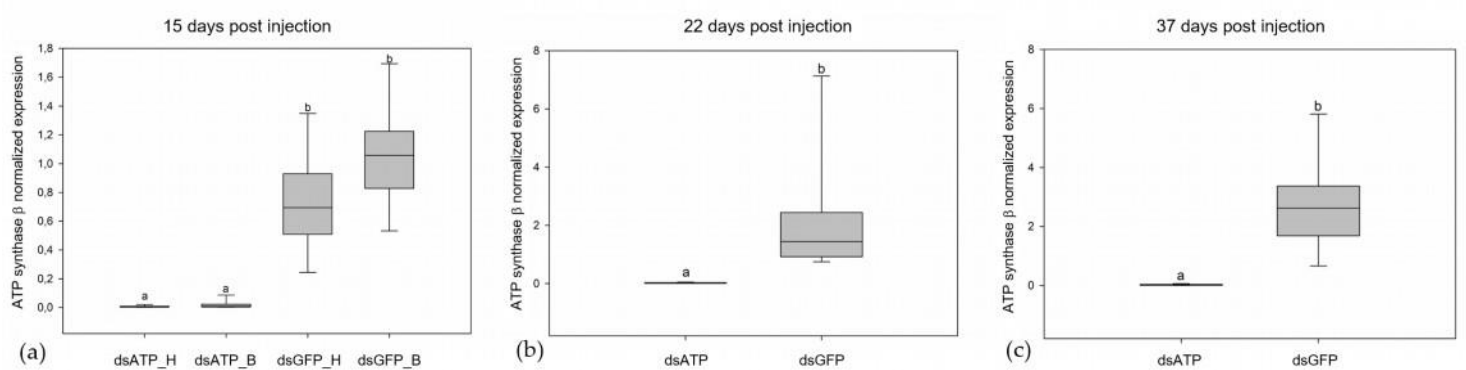

Figure 2. Transcript level of ATP synthase $\beta$ in insects injected with dsRNAs. Transcript level of ATP synthase $\beta$ in insects injected with dsRNAs targeting ATP synthase $\beta$ (dsATP) or Green Fluorescent Protein (dsGFP) at 15 (a), 22 (b) and 37 (c) days post injection (dpi). At 15 dpi (a), transcript levels were measured separately in heads (_H) and abdomens (_B) of the different treated insect groups. At 22 (b) and 37 (c) dpi, transcript levels were measured in the whole body. The median is depicted as the line across the box, the box indicates the $25^{\text {th }}$ and $75^{\text {th }}$ percentiles, whiskers represent the $90^{\text {th }}$ and $10^{\text {th }}$ percentiles and different letters indicate significant differences between treatments.

\subsection{Generation of dsRNA-derived siRNAs}

Total sRNA reads mapping to the dsATP sequence in Eva_ATP libraries (Figure 3a) and the dsGFP sequence in Eva_GFP libraries (Figure 3b) showed the same length distributions, the majority being in the 19-22 nt range with a peak at $21 \mathrm{nt}$ (Supplementary Table S3). These observations confirmed that the silencing mechanism was still active at least until $22 \mathrm{dpi}$.

In Eva_ATP libraries, sRNA reads mapped exclusively to the fragment of the ATP synthase $\beta$ transcript corresponding to the injected dsATP (Figure 3c). In both Eva_ATP and Eva_GFP libraries, sRNA covered the whole length of the corresponding dsRNA targets, with an uneven distribution. Two main hotspots could be observed between nt 247 and 362 in the dsATP sequence (Figure 3c), whereas in the dsGFP sequence, two peaks were clearly visible between nt 202 and 278 (Figure 3d). In both conditions hotspots were made up mostly of $21 \mathrm{nt}$-long sRNAs.

It is noteworthy that in four out of $12 \mathrm{dsGFP-injected} \mathrm{insects} \mathrm{collected} \mathrm{at} 22 \mathrm{dpi}$ it was still possible to amplify the whole dsGFP sequence (data not shown), thus revealing unexpected long-term stability of dsRNAs. An analogous RT-PCR was not carried out on dsATP-injected insects, as in that case, it was impossible to discriminate the presence of intact dsATP from residual ATP synthase $\beta$ transcripts. 
(a)

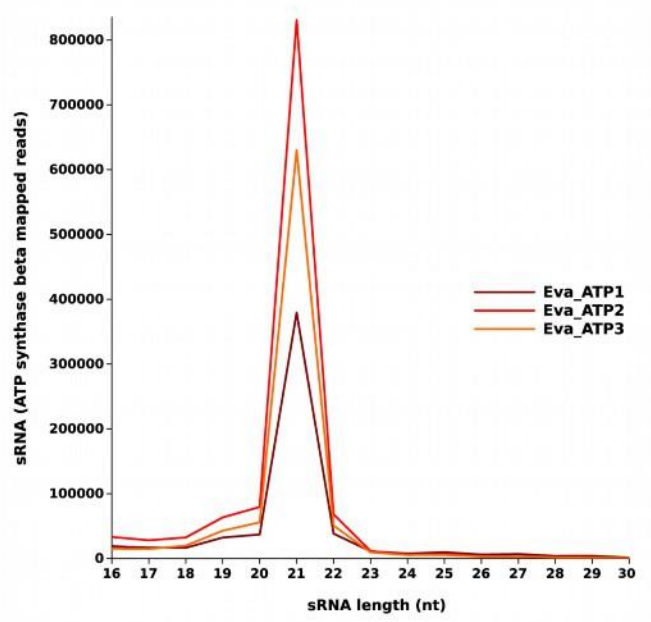

(b)

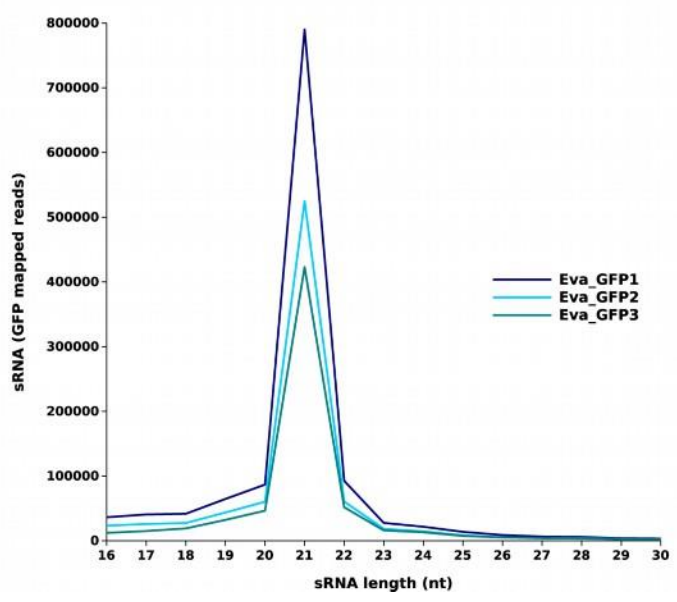

(c)

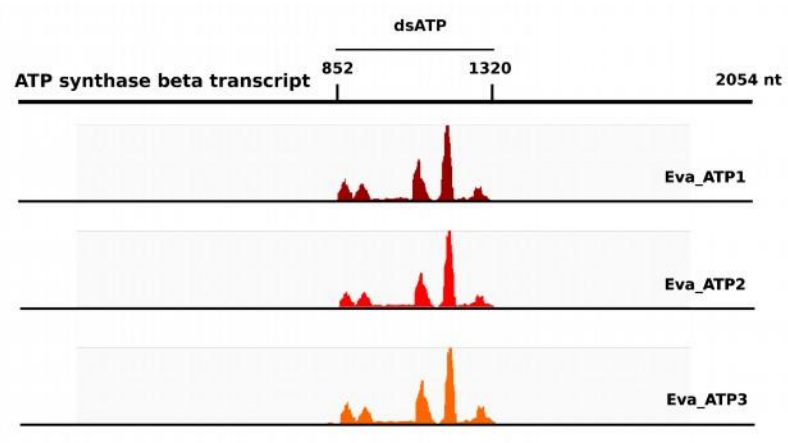

(d)

Figure 3. Analysis of smallRNAs profile. sRNA length distribution and mapping to ATP synthase $\beta$ and Green Fluorescent Protein (GFP) in dsATP injected and dsGFP injected insects, respectively, at 22 days post injection (dpi). (a) Length distribution of sRNA mapping to the ATP synthase $\beta$ transcript in the three libraries obtained from dsATP-injected insects. (b) Length distribution of sRNA mapping to the GFP in the three libraries obtained from dsGFP-injected insects (c) sRNA distribution over the whole length of the ATP synthase $\beta$ transcript in the three libraries obtained from dsATP-injected insects. No sRNAs mapped outside the region corresponding to the injected dsATP. (d) sRNA distribution over the dsGFP sequence in the three libraries obtained from dsGFP-injected insects.

\subsection{Silencing of ATP synthase $\beta$ gene affects the amount of encoded protein}

Insects collected at 4, 6, 8, 12, and 15 dpi from the two treatments (dsATP vs. dsGFP) were analyzed by Western blot to quantify the amount of the corresponding ATP synthase $\beta$ protein. The anti-ATP synthase $\beta$ antibody recognized a protein of about $55 \mathrm{kDa}$ (Supplementary Figure S1), as expected from in silico translation of the coding sequence (theoretical $\mathrm{pI} / \mathrm{Mw}$ : 5.20/55.7 $\mathrm{kDa}$ ). The protein expression level was similar in the two insect groups up to $12 \mathrm{dpi}$, whereas at $15 \mathrm{dpi}$ the protein amount detected in the six insects injected with dsATP was about 2.5 times lower ( $t$ test, $\mathrm{t}=4.510, \mathrm{P}<0.001)$ than that observed in the six insects injected with dsGFP 
(Figure 4a, b, and Supplementary Table S4). Coomassie staining of the same protein samples separated by SDS-PAGE confirmed that equal amounts of proteins from the two insect groups were loaded into gels (Supplementary Figure S1).

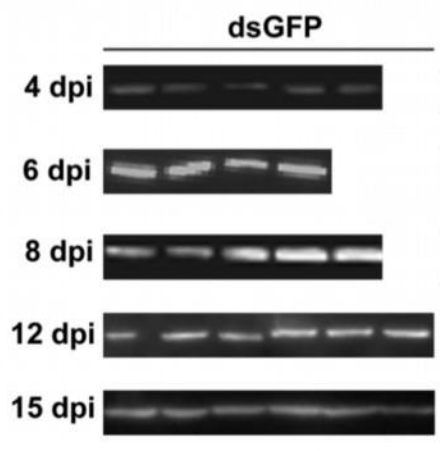

(a)

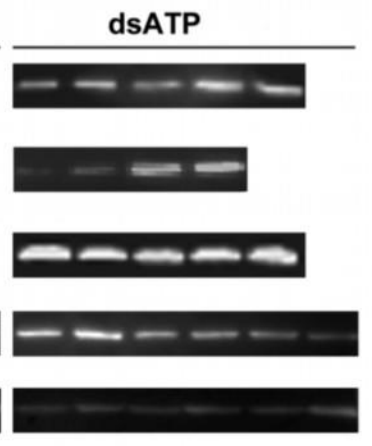

(b)

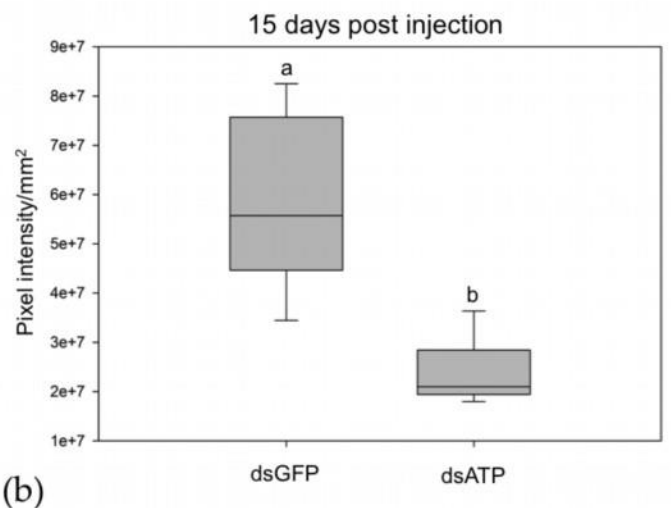

Figure 4. Protein level of ATP synthase $\beta$ in insects injected with dsRNAs. (a) Protein expression of ATP synthase $\beta$ analysed by Western blots on Euscelidius variegatus insects (one insect sample per lane) injected with dsRNAs targeting ATP synthase $\beta$ (dsATP) or Green Fluorescent Protein (dsGFP) at 4, 6, 8, 12 and 15 days post injection (dpi). (b) Pixel intensity $/ \mathrm{mm}^{2}$ of Western blots bands depicted in (a) measured in insects analysed at $15 \mathrm{dpi}$. This parameter is the sum of the intensity of each pixel calculated by Quantity One 1-D Analysis Software (BioRad) included in the band boundary manually defined. The median is depicted as the line across the box, the box indicates the $25^{\text {th }}$ and $75^{\text {th }}$ percentiles, whiskers represent the $90^{\text {th }}$ and $10^{\text {th }}$ percentiles and different letters indicate significant differences between treatments.

\subsection{Silencing of ATP synthase $\beta$ reduces pathogen multiplication, while it has no effect on prevalence of infected insects}

Insects injected with either dsATP or dsGFP successfully acquired either CYp or FDp during feeding on infected plants, as all analysed insects tested positive in RTqPCR for the presence of both pathogens (Table 1).

Table 1. Phytoplasma acquisition by insects after silencing of ATP synthase $\beta$. Acquisition of phytoplasmas by Euscelidius variegatus insects, sampled at 22 days post injection of dsRNAs targeting ATP synthase $\beta$ or green fluorescent protein (GFP) and at 7 days post acquisition of chrysanthemum yellows (CYp) or Flavescence dorée (FDp) phytoplasmas, as detailed in methodology depicted in Figure 1.

\begin{tabular}{ccc}
\hline $\begin{array}{c}\text { Target of } \\
\text { dsRNAs }\end{array}$ & $\begin{array}{c}\text { Phytoplasma acquired } \\
\text { post dsRNA injection }\end{array}$ & $\begin{array}{c}\text { Phytoplasma } \\
\text { positive/analysed insects }\end{array}$ \\
\hline ATP synthase $\beta$ & CYp & $42 / 42$ \\
\hline GFP & CYp & $43 / 43$ \\
\hline ATP synthase $\beta$ & FDp & $39 / 39$ \\
\hline GFP & FDp & $36 / 36$ \\
\hline
\end{tabular}

On the contrary, significant differences were observed in phytoplasma mean quantities measured in insects injected with dsATP compared with those measured in insects injected with dsGFP, for both CYp and FDp (Figure 5 and Supplementary 
Table S5; Mann-Whitney $\mathrm{U}=597, \mathrm{~T}=1500, \mathrm{P}=0.007$ for CYp and $\mathrm{U}=466, \mathrm{~T}=1604$, $\mathrm{P}=0.013$ for FDp). Mean CYp and FDp amounts in dsATP insects were five and four time lower than those measured in corresponding dsGFP-injected specimens, indicating that silencing of ATP synthase $\beta$ reduced multiplication rates of both pathogens. The copy number of CYp 16S RNA per insect GAPDH transcript ranged from 1.83E-06 to 7.56E-02 with a median of 1.79E-03 in dsATP-injected insects and from $1.08 \mathrm{E}-05$ to $2.50 \mathrm{E}-01$ with a median of $4.88 \mathrm{E}-03$ in dsGFP-injected ones. The copy number of FDp 16S RNA per insect GAPDH transcript ranged from 3.67E-07 to $3.34 \mathrm{E}-01$ with a median of $1.89 \mathrm{E}-03$ in dsATP insects and from 8.50E-06 to 5.45E01 with a median of $1.24 \mathrm{E}-02$ in dsGFP insects.
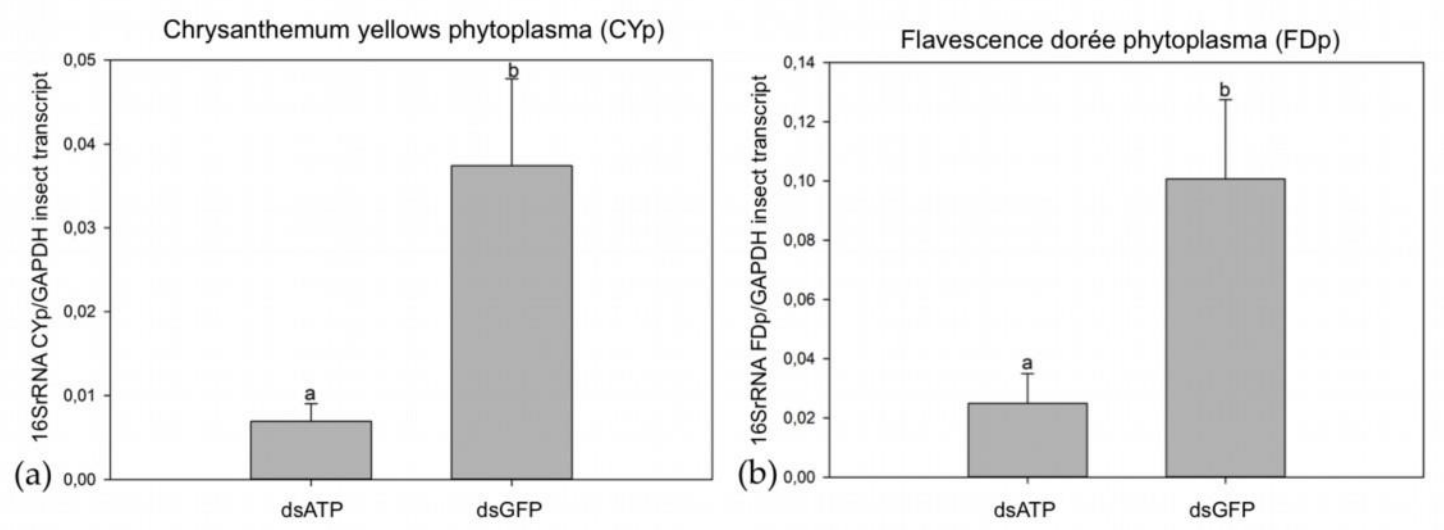

Figure 5. Phytoplasma amount in insects after silencing of ATP synthase $\beta$. Mean phytoplasma 16S RNA/insect GAPDH transcript \pm standard error of the mean (SEM) measured in Euscelidius variegatus insects, sampled at 22 days post injection of dsRNAs targeting ATP synthase $\beta$ (dsATP) or green fluorescent protein (dsGFP). Twenty-two days post injection correspond to 7 days post acquisition of chrysanthemum yellows (CYp, panel a) or Flavescence dorée (FDp, panel b) phytoplasmas. Different letters indicate significant differences in mean phytoplasma amount.

\section{Discussion}

The present work shows that silencing of an insect vector gene, involved in interaction with the antigenic membrane protein of the transmitted phytoplasma, suppresses phytoplasma multiplication in the insect body. Since its discovery, RNAi has emerged as a powerful molecular tool for studying gene function, regulation, and interaction at the cell and organism levels. RNAi is particularly efficient in some insects, especially those included in the Coleoptera order, whereas species within Lepidoptera and Hemiptera may show variable attitudes in response to RNAi (Zhu and Palli, 2020; Zotti et al., 2018). Several efforts have been made using RNAi in hemipterans. In most of these cases, target genes for silencing were selected to achieve insect mortality, but in few instances RNAi was applied to interfere with vector ability. To this purpose, silencing of viral genes involved in interaction with vector proteins has been exploited, as revised in (Kanakala and Ghanim, 2016). In Laodelphax striatellus, silencing of Argonaute 2 enhanced the accumulation of the 
insect-specific Himetobi P picorna-like virus (Xu et al., 2014), and silencing of the cuticular protein CPR1 decreased transmission ability of rice stripe tenuivirus by the same planthopper (Liu et al., 2015). Silencing of Bemisia tabaci heat shock proteins disrupted interactions with tomato yellow leaf curl begomoviruses (Gotz et al., 2012; Ohnesorge and Bejarano, 2009). Here, silencing of ATP synthase $\beta$ gene of the phytoplasma vector E. variegatus, besides confirming the vital role of this gene for efficient phytoplasma colonization of the vector body, represents the first attempt to disrupt phytoplasma-vector interactions, and paves the way to new strategies to interfere with phytoplasma transmission. Moreover, this mechanism seems to be conserved in two genetically unrelated phytoplasma species.

Gene silencing mediated by RNAi spread systemically in the leafhopper, as demonstrated by the reduction of ATP synthase $\beta$ transcripts in the heads of insects after abdominal microinjection with the triggering dsRNA molecules. Two mechanisms of cellular uptake of dsRNAs have been identified in insects: Sid-like transmembrane channels, and clathrin-dependent endocytosis (Christiaens et al., 2020). SID-1 is a channel protein responsible for binding long dsRNAs for uptake by cells and is required for the systemic RNAi response in the nematode Caenorhabditis elegans, the organism in which RNAi has been first described (Fire et al., 1998). Sidlike genes have been identified in Coleoptera, Hemiptera, and Lepidoptera, but their role in cellular uptake has not been directly evidenced to date (Christiaens et al., 2020; Vélez and Fishilevich, 2018). Despite initially the Sid-1 gene was not included among the key components of the E. variegatus RNAi machinery (Abbà et al., 2019), a manual analysis of the transcriptome confirmed its presence in this species. The Sid-1 coding sequence was, in fact, identified in the TSA entry GFTU01001708.1 from nt 7024 to nt 9375 on the reverse strand (Simona Abbà, personal communication). The presence of this gene in E. variegatus suggests its possible involvement in dsRNA uptake and in the spread of gene-silencing signals to adjacent tissues.

Injection of dsATP in E. variegatus determined a long-lasting reduction of the corresponding transcript by an average 100-fold compared to dsGFP controls, and the silencing was still efficient at least up to 37 days after the injection. Duration of RNAi is highly variable among insects. For example, the flour beetle Tenebrio molitor shows a robust RNAi response with gene suppression in virtually any cell type and also inheritance to progeny, whereas in Drosophila gene silencing is often shorttermed and limited to few cell types (Bucher et al., 2002; Miller et al., 2008). Huge variability has been also described within Hemiptera order. In the pea aphid Acyrthosiphon pisum RNAi silencing of two marker genes starts one day after dsRNA injection, reaches its maximum at 5 days and stops at 7 days (Jaubert-Possamai et al., 2007). On the other hand, plant-mediated RNAi in the green peach aphid Myzus persicae has been shown to last up to 16 days and to be retained in the progeny when insects are continuously fed on dsRNA-producing transgenic Arabidopsis thaliana, whereas the silencing effect disappears within 6 days when the aphids are removed from the transgenic plants (Coleman et al., 2015). Parental RNAi has been demonstrated to occur also in the green rice leafhopper Nephotettix cincticeps, as 
injection of dsRNAs silences target genes at least up to $14 \mathrm{dpi}$ in parent females as well as in the $1^{\text {st }}$ instar offspring nymphs (Matsumoto and Hattori, 2016). Parental RNAi has been confirmed in the triatomine bug Rhodnius prolixus, and interestingly the knockdown effects of three target genes persisted in this species up to 7 months after the dsRNA injection (Paim et al., 2013). Whether the long-term effect is still mediated by the primary dsRNA molecules initially injected or due to a secondary propagation of RNAi signal is unclear. Nevertheless, some hints may be deduced by the analysis of the sRNA pattern profiles obtained from silenced insects in comparison with GFP treated controls. Total sRNA reads mapping to the dsATP sequence in Eva_ATP libraries and the dsGFP sequence in Eva_GFP libraries showed length distributions of sRNA consistent with the processing of dsRNA into siRNA by the RNAi pathway, as previously observed in other insects (Santos et al., 2019). Interestingly, sRNA reads mapped exclusively to the fragment of the ATP synthase $\beta$ transcript covering the injected dsATP. The lack of read coverage over the rest of the $2054 \mathrm{nt}$-long transcript pointed against the existence in E. variegatus of mechanisms of secondary siRNA synthesis similar to those observed in plants and nematodes (Christiaens et al., 2020). Consistently, the detection of intact dsGFP in some specimens at $22 \mathrm{dpi}$ suggests that the long-term silencing could be due to an inefficient degradation of the injected dsRNAs, which continued to trigger the silencing machinery. Even though systemic RNAi is observed in insects, the specific mechanisms, genes involved in the spread of dsRNAs, and the kind of signal molecules (either dsRNA or siRNA) are yet to be unraveled (Vélez and Fishilevich, 2018). In the case of viral infection of Drosophila, transport of dsRNA through the insect body may occur via derived complementary viral DNAs used as template for de novo synthesis of secondary viral siRNAs in hemocytes and released in exosomes (Tassetto et al., 2017). Nanotube-like structures observed in D. melanogaster culture cells may also be one of the mechanisms of antiviral RNAi machinery transport between infected and non-infected cells (Karlikow et al., 2016).

Beside the reduction of the specific transcript, a significant decrease of the corresponding protein occurred starting from 15 days after dsRNA injection. The delay of the observed effect at protein level is consistent with the assembly of the mitochondrial respiratory complexes, which exploit oversynthesis of the nucleusencoded proteins to provide an adequate molecule supply for the assembly process (Bogenhagen and Haley, 2020). Determining the effect of dsRNA injection on protein expression allowed us to optimize experiments with a proper time scale, as phytoplasma acquisition was performed only when the effect of gene silencing was evident at the protein level. Even though no effect was observed on phytoplasma acquisition efficiency, as all insects tested positive for the phytoplasma presence irrespective of dsATP or dsGFP injections, a significant lower pathogen amount was measured in silenced insects compared with the controls. ATP synthase $\beta$ is already known to interact in vitro with the phytoplasma major Antigenic membrane protein (Galetto et al., 2011), function as a viral receptor (G.-F. Liang et al., 2015; Liang et al., 2010) and mediate the entry of viral particles into host arthropod cells (Fongsaran et 
al., 2014). Our data, are in line with this role of ATP synthase $\beta$. Interestingly, for a long time $\mathrm{F}_{1}-\mathrm{F}_{0}$ ATP synthase complex was thought to be exclusively located in the inner membrane of mitochondria, but more and more clues are pointing at the existence of ATP synthases on the outer face of plasma membranes of many cell lines and tissues of mammals, as reviewed in (Taurino and Gnoni, 2018), and arthropods (Fongsaran et al., 2014; Y. Liang et al., 2015; Lin et al., 2009). Moreover, the synthesis of extracellular ATP produced by $\mathrm{F}_{1}-\mathrm{F}_{0}$ complex expressed on plasma membranes has been documented for a wide variety of cells, mainly mammalian adipocytes, keratinocytes, endothelial, and hepatic cells (Taurino and Gnoni, 2018), but also primary cell lines of the yellow fever mosquito Aedes aegypti (Fongsaran et al., 2014) and hemocytes of the Pacific white shrimp Litopenaeus vannamei (Y. Liang et al., 2015). The ectopic expression of ATP synthase $\beta$ in plasma membranes has been shown in midguts and salivary glands of E. variegatus (Galetto et al., 2011), so we may assume that the synthesis of extracellular ATP also occurs in E. variegatus. In addition, it is noteworthy that phytoplasmas lack the ATP synthetic pathway and strongly depend on their hosts for energy metabolism (Oshima et al., 2004). Therefore, a decrease in extracellular ATP caused by the silencing of ATP synthase $\beta$ may impair the survival of phytoplasma cells and explain the observed reduction in the pathogen multiplication rate. The uptake of host-synthesized ATP seems to be a mechanism commonly shared by different phytoplasmas, as the phylogenetically distant CYp and FDp behaved similarly. Host-synthesized ATP plays a role during binding and successive infection process of the Pacific white shrimp by the white spot syndrome virus (Y. Liang et al., 2015). Phytoplasma transmission depends on the level of phytoplasma multiplication in the vector, as shown for CYp (Bosco et al., 2007; Galetto et al., 2009), and apple proliferation phytoplasma (Cainelli et al., 2007; Mayer et al., 2009), therefore the specific silencing of vector ATP synthase $\beta$ may become part of a strategy aimed at reducing insecticide use against less efficient vectors. Indeed, the strong, long-lasting, and systemic nature of the observed gene silencing after a single dose of dsATP may theoretically identify RNAi as a suitable control strategy against phytoplasma insect vectors. From a practical point of view, dsRNA delivery to sap-sucking insects remains a big unsolved issue, despite new technologies and innovative approaches are envisaged (Christiaens et al., 2020). In the case, for example, of the Asian citrus psyllid Diaphorina citri, vector of citrus Huanglongbing, dsRNAs were successfully delivered by soaking insects in dsRNA-containing solutions (Killiny et al., 2014; Yu et al., 2017) and by feeding them on an optimized plant system (iPS) bioassay (Andrade and Hunter, 2017).

\section{Conclusions}

Silencing of ATP synthase $\beta$ of E. variegatus decreased multiplication of two unrelated phytoplasmas in the vector body. As silencing of this gene resulted in the decrease of the corresponding protein, a role of ATP synthase $\beta$ in mediating phytoplasma multiplication in vivo is suggested. This comprehensive study 
analyzed changes in transcript levels, protein expression, and sRNA profiles triggered by dsRNA injection. Gene silencing spreads systemically with unexpected long-lasting effects, which probably depend on insufficient dsRNA degradation rather than the production of secondary siRNAs, as suggested by the sRNA profiles. The presence of such a robust RNAi machinery is of immense interest, especially in the case of insect vectors of phytoplasmas, as it may be exploited as a possible tool to disrupt transmission and integrated in pest management programs to face phytoplasma diseases (Sattar and Thompson, 2016).

\section{Supplementary Materials}

Table S1: Primers and probes, Table S2: Mean expression values of ATP synthase $\beta$ transcript, Table S3: sRNA length distributions on dsRNA targets in the six sRNA libraries, Table S4: Pixel intensity values of Western blots images, Table S5: Phytoplasma detection and mean pathogen quantification values, Figure S1: Full length images of Western blots and corresponding SDS-polyacrylamide gels.

\section{Author Contributions}

Conceptualization, L.G., S.A., D.B. and C.M.; methodology and investigation, L.G., S.A., M.Ro., M.Ri., and S.P.; writing-original draft preparation, L.G. and S.A.; writing-review and editing, M.Ro., S.P., D.B. and C.M.; funding acquisition, L.G., S.A., D.B. and C.M. All authors have read and agreed to the published version of the manuscript.

\section{Acknowledgments}

This project has received funding from the European Union's Horizon 2020 research and innovation programme under grant agreement No 773567. This research was also supported by Fondazione Cassa di Risparmio di Torino, Projects Siglofit $(\mathrm{RF}=2016-0577)$ and FOotSTEP $(\mathrm{RF}=2018-0678)$.

The authors thank Elena Zocca for providing plants for insect rearing, Flavio Veratti and Francesca Canuto for maintenance of insect colonies, Giulia Molinatto for helping in microinjection procedure. 


\section{References}

Abbà, S., Galetto, L., Ripamonti, M., Rossi, M., Marzachì, C., 2019. RNA interference of muscle actin and ATP synthase beta increases mortality of the phytoplasma vector Euscelidius variegatus. Pest Manag. Sci. 75, 1425-1434. https://doi.org/10.1002/ps.5263

Andrade, E.C., Hunter, W.B., 2017. RNAi feeding bioassay: development of a nontransgenic approach to control Asian citrus psyllid and other hemipterans. Entomol. Exp. Appl. 162, 389-396. https://doi.org/10.1111/eea.12544

Bogenhagen, D.F., Haley, J.D., 2020. Pulse-chase SILAC-based analyses reveal selective oversynthesis and rapid turnover of mitochondrial protein components of respiratory complexes. J. Biol. Chem. 295, 2544-2554. https://doi.org/10.1074/jbc.RA119.011791

Bosco, D., Galetto, L., Leoncini, P., Saracco, P., Raccah, B., Marzachì, C., 2007. Interrelationships between "Candidatus Phytoplasma asteris" and its leafhopper vectors (Homoptera: Cicadellidae). J. Econom. Entomol. 100, 1504-1511. https://doi.org/10.1603/0022-0493-100.5.1504

Bosco, D., Marzachì, C., 2016. Insect transmission of phytoplasmas, in: Brown, J.K. (Ed.), Vector-Mediated Transmission of Plant Pathogens. APS Press, St. Paul, Minnesota, pp. 319-327.

Bucher, G., Scholten, J., Klingler, M., 2002. Parental RNAi in Tribolium (Coleoptera). Curr. Biol. 12, R85-86. https://doi.org/10.1016/s0960-9822(02)00666-8

Bushnell, B., 2014. A fast, accurate, splice-aware aligner. 2014 Available online: https://sourceforge.net/projects/bbmap/ (accessed on 07/08/2019).

Cainelli, C., Forno, F., Mattedi, L., Grando, M.S., 2007. Can apple aphids be vectors of “Candidatus Phytoplasma mali”? IOBC/WPRS Bulletin 30, 261-266.

Candiano, G., Bruschi, M., Musante, L., Santucci, L., Ghiggeri, G.M., Carnemolla, B., Orecchia, P., Zardi, L., Righetti, P.G., 2004. Blue silver: A very sensitive colloidal Coomassie G-250 staining for proteome analysis. Electrophoresis 25, 1327-1333. https://doi.org/10.1002/elps.200305844

Caudwell, A., Kuszala, C., Larrue, J., Bachelier, J., 1972. Transmission de la Flavescence dorée de la fève à la fève par des cicadelles des genres Euscelis et Euscelidius. Ann. Phytopathol. No. hors série, 181-189.

Chen, Y., Redinbaugh, M.G., Michel, A.P., 2015. Molecular interactions and immune responses between Maize fine streak virus and the leafhopper vector Graminella nigrifrons through differential expression and RNA interference: virus defense and RNAi in $G$. nigrifons. Insect Mol. Biol. 24, 391-401. https://doi.org/10.1111/imb.12166

Christiaens, O., Whyard, S., Vélez, A.M., Smagghe, G., 2020. Double-stranded RNA technology to control insect pests: current status and challenges. Front. Plant Sci. 11, 451. https://doi.org/10.3389/fpls.2020.00451

Coleman, A.D., Wouters, R.H.M., Mugford, S.T., Hogenhout, S.A., 2015. Persistence and transgenerational effect of plant-mediated RNAi in aphids. J. Exp. Botany 66, 541-548. https://doi.org/10.1093/jxb/eru450 
Conti, M., D’Agostino, G., Casetta, A., Mela, L., 1988. Some characteristics of chrysanthemum yellows disease. Acta Horticult. 129-136. https://doi.org/10.17660/ActaHortic.1988.234.15

EFSA Panel on Plant Health PLH, 2014. Scientific opinion on pest categorisation of grapevine Flavescence dorée: grapevine Flavescence dorée pest categorisation. EFSA J. 12, 3851. https://doi.org/10.2903/j.efsa.2014.3851

EFSA Panel on Plant Health PLH, Jeger, M., Bragard, C., Caffier, D., Candresse, T., Chatzivassiliou, E., Dehnen- Schmutz, K., Gilioli, G., Jaques Miret, J.A., MacLeod, A., Navajas Navarro, M., Niere, B., Parnell, S., Potting, R., Rafoss, T., Rossi, V., Urek, G., Van Bruggen, A., Van Der Werf, W., West, J., Winter, S., Bosco, D., Foissac, X., Strauss, G., Hollo, G., Mosbach- Schulz, O., Grégoire, J., 2016. Risk to plant health of Flavescence dorée for the EU territory. EFSA J. 14, 4603. https://doi.org/10.2903/j.efsa.2016.4603

Fire, A., Xu, S., Montgomery, M.K., Kostas, S.A., Driver, S.E., Mello, C.C., 1998. Potent and specific genetic interference by double-stranded RNA in Caenorhabditis elegans. Nature 391, 806-811. https://doi.org/10.1038/35888

Fongsaran, C., Jirakanwisal, K., Kuadkitkan, A., Wikan, N., Wintachai, P., Thepparit, C., Ubol, S., Phaonakrop, N., Roytrakul, S., Smith, D.R., 2014. Involvement of ATP synthase $\beta$ subunit in chikungunya virus entry into insect cells. Arch. Virol. 159, 3353-3364. https://doi.org/10.1007/s00705-014-2210-4

Galetto, L., Abbà, S., Rossi, M., Vallino, M., Pesando, M., Arricau-Bouvery, N., Dubrana, M.-P., Chitarra, W., Pegoraro, M., Bosco, D., Marzachì, C., 2018. Two phytoplasmas elicit different responses in the insect vector Euscelidius variegatus Kirschbaum. Infect. Immun. 86, IAI.00042-18. https://doi.org/10.1128/IAI.00042-18

Galetto, L., Bosco, D., Balestrini, R., Genre, A., Fletcher, J., Marzachì, C., 2011. The major antigenic membrane protein of "Candidatus Phytoplasma asteris" selectively interacts with ATP synthase and actin of leafhopper vectors. PLoS ONE 6, e22571; 10.1371/journal.pone.0022571. https://doi.org/10.1371/journal.pone.0022571

Galetto, L., Miliordos, D., Roggia, C., Rashidi, M., Sacco, D., Marzachì, C., Bosco, D., 2014. Acquisition capability of the grapevine Flavescence dorée by the leafhopper vector Scaphoideus titanus Ball correlates with phytoplasma titre in the source plant. J. Pest Sci. 87, 671-679. https://doi.org/10.1007/s10340-014-0593-3

Galetto, L., Nardi, M., Saracco, P., Bressan, A., Marzachì, C., Bosco, D., 2009. Variation in vector competency depends on chrysanthemum yellows phytoplasma distribution within Euscelidius variegatus. Entomol. Exp. Appl. 131, 200-207. https://doi.org/10.1111/j.15707458.2009.00845.x

Gotz, M., Popovski, S., Kollenberg, M., Gorovits, R., Brown, J.K., Cicero, J.M., Czosnek, H., Winter, S., Ghanim, M., 2012. Implication of Bemisia tabaci heat shock protein 70 in Begomovirus-whitefly interactions. Journal of Virology 86, 13241-13252. https://doi.org/10.1128/JVI.00880-12

Jarausch, W., Torres, E., 2014. Management of phytoplasma-associated diseases, in: Phytoplasmas and Phytoplasma Disease Management: How to Reduce Their Economic 
Impact. Bertaccini A. Ed., pp. 199-208.

Jaubert-Possamai, S., Le Trionnaire, G., Bonhomme, J., Christophides, G.K., Rispe, C., Tagu, D., 2007. Gene knockdown by RNAi in the pea aphid Acyrthosiphon pisum. BMC Biotechnol. 7, 63. https://doi.org/10.1186/1472-6750-7-63

Kanakala, S., Ghanim, M., 2016. RNA interference in insect vectors for plant viruses. Viruses 8, 329. https://doi.org/10.3390/v8120329

Karlikow, M., Goic, B., Mongelli, V., Salles, A., Schmitt, C., Bonne, I., Zurzolo, C., Saleh, M.-C., 2016. Drosophila cells use nanotube-like structures to transfer dsRNA and RNAi machinery between cells. Sci. Rep. 6, 27085. https://doi.org/10.1038/srep27085

Killiny, N., Hajeri, S., Tiwari, S., Gowda, S., Stelinski, L.L., 2014. Double-stranded RNA uptake through topical application mediates silencing of five CYP4 genes and suppresses insecticide resistance in Diaphorina citri. PLoS ONE 9, e110536. https://doi.org/10.1371/journal.pone.0110536

Koinuma, H., Maejima, K., Tokuda, R., Kitazawa, Y., Nijo, T., Wei, W., Kumita, K., Miyazaki, A., Namba, S., Yamaji, Y., 2020. Spatiotemporal dynamics and quantitative analysis of phytoplasmas in insect vectors. Sci. Rep. 10, 4291. https://doi.org/10.1038/s41598-020-61042-x

Langmead, B., 2010. Aligning short sequencing reads with Bowtie. Curr. Protoc. Bioinform. 32. https://doi.org/10.1002/0471250953.bi1107s32

Lee, I.-M., 2004. "Candidatus Phytoplasma asteris", a novel phytoplasma taxon associated with aster yellows and related diseases. Int. J. Syst. Evol. Microbiol. 54, 10371048. https://doi.org/10.1099/ijs.0.02843-0

Leyva, J.A., Bianchet, M.A., Amzel, L.M., 2003. Understanding ATP synthesis: structure and mechanism of the F1-ATPase. Mol. Membr. Biol. 20, 27-33. https://doi.org/10.1080/0968768031000066532

Li, H., Handsaker, B., Wysoker, A., Fennell, T., Ruan, J., Homer, N., Marth, G., Abecasis, G., Durbin, R., 1000 Genome Project Data Processing Subgroup., 2009. The sequence alignment/map format and SAMtools. Bioinformatics 25, 2078-2079. https://doi.org/10.1093/bioinformatics/btp352

Liang, G.-F., Liang, Y., Xue, Q., Lu, J.-F., Cheng, J.-J., Huang, J., 2015. Astakine LvAST binds to the $\beta$ subunit of F1-ATP synthase and likely plays a role in white shrimp Litopeneaus vannamei defense against white spot syndrome virus. Fish Shell. Immunol. 43, 75-81. https://doi.org/10.1016/j.fsi.2014.12.015

Liang, Y., Cheng, J.-J., Yang, B., Huang, J., 2010. The role of F1 ATP synthase beta subunit in WSSV infection in the shrimp, Litopenaeus vannamei. Virol J. 7, 144. https://doi.org/10.1186/1743-422X-7-144

Liang, Y., Xu, M.-L., Wang, X.-W., Gao, X.-X., Cheng, J.-J., Li, C., Huang, J., 2015. ATP synthesis is active on the cell surface of the shrimp Litopenaeus vannamei and is suppressed by WSSV infection. Virol J. 12, 49. https://doi.org/10.1186/s12985-015-0275-7

Lin, X., Kim, Y.-A., Lee, B.L., Söderhäll, K., Söderhäll, I., 2009. Identification and properties of a receptor for the invertebrate cytokine astakine, involved in hematopoiesis. 
Exp. Cell Res. 315, 1171-1180. https://doi.org/10.1016/j.yexcr.2009.01.001

Liu, W., Gray, S., Huo, Y., Li, L., Wei, T., Wang, X., 2015. Proteomic analysis of interaction between a plant virus and its vector insect reveals new functions of Hemipteran cuticular protein. Mol. Cell Proteomics 14, 2229-2242. https://doi.org/10.1074/mcp.M114.046763

Marcone, C., 2014. Molecular biology and pathogenicity of phytoplasmas. Ann. Appl. Biol. 165, 199-221. https://doi.org/10.1111/aab.12151

Martin, M., 2011. Cutadapt removes adapter sequences from high-throughput sequencing reads. EMBnet J. 17, 10. https://doi.org/10.14806/ej.17.1.200

Marzachí, C., Bosco, D., 2005. Relative quantification of chrysanthemum yellows (16SrI) phytoplasma in its plant and insect host using real-time polymerase chain reaction. Mol. Biotechnol. 30, 117-128. https://doi.org/10.1385/MB:30:2:117

Matsumoto, Y., Hattori, M., 2016. Gene silencing by parental RNA interference in the green rice leafhopper, Nephotettix cincticeps (Hemiptera: Cicadellidae): parental RNAi in Nephotettix cincticeps. Arch. Insect Biochem. Physiol. 91, 152-164. https://doi.org/10.1002/arch.21315

Mayer, C.J., Jarausch, B., Jarausch, W., Jelkmann, W., Vilcinskas, A., Gross, J., 2009. Cacopsylla melanoneura has no relevance as vector of apple proliferation in Germany. Phytopathol. 99, 729-738. https://doi.org/10.1094/PHYTO-99-6-0729

Miller, S.C., Brown, S.J., Tomoyasu, Y., 2008. Larval RNAi in Drosophila? Dev. Genes Evol. 218, 505-510. https://doi.org/10.1007/s00427-008-0238-8

Ohnesorge, S., Bejarano, E.R., 2009. Begomovirus coat protein interacts with a small heat-shock protein of its transmission vector (Bemisia tabaci). Insect Mol. Biol. 18, 693-703. https://doi.org/10.1111/j.1365-2583.2009.00906.x

Oshima, K., Kakizawa, S., Nishigawa, H., Jung, H.-Y., Wei, W., Suzuki, S., Arashida, R., Nakata, D., Miyata, S., Ugaki, M., Namba, S., 2004. Reductive evolution suggested from the complete genome sequence of a plant-pathogenic phytoplasma. Nat. Genet. 36, 27-29. https://doi.org/10.1038/ng1277

Ottati, S., Persico, A., Rossi, M., Bosco, D., Vallino, M., Abbà, S., Molinatto, G., Palmano, S., Balestrini, R., Galetto, L., Marzachì, C., 2020. Biological characterization of Euscelidius variegatus iflavirus 1. J. Invertebr. Pathol. 173, 107370. https://doi.org/10.1016/j.jip.2020.107370

Paim, R.M.M., Araujo, R.N., Lehane, M.J., Gontijo, N.F., Pereira, M.H., 2013. Longterm effects and parental RNAi in the blood feeder Rhodnius prolixus (Hemiptera; Reduviidae). Insect Biochem. Mol. Biol. 43, 1015-1020. https://doi.org/10.1016/j.ibmb.2013.08.008

Rashidi, M., D’Amelio, R., Galetto, L., Marzachì, C., Bosco, D., 2014. Interactive transmission of two phytoplasmas by the vector insect. Ann. Appl. Biol. 165, 404-413. https://doi.org/10.1111/aab.12146

Rashidi, M., Galetto, L., Bosco, D., Bulgarelli, A., Vallino, M., Veratti, F., Marzachì, C., 2015. Role of the major antigenic membrane protein in phytoplasma transmission by two 
insect vector species. BMC Microbiol. 15, 193; 10.1186/s12866-015-0522-5. https://doi.org/10.1186/s12866-015-0522-5

Robinson, J.T., Thorvaldsdóttir, H., Wenger, A.M., Zehir, A., Mesirov, J.P., 2017. Variant review with the integrative genomics viewer. Cancer Res. 77, e31-e34. https://doi.org/10.1158/0008-5472.CAN-17-0337

Rossi, M., Samarzija, I., Šeruga-Musić, M., Galetto, L., 2019. Diversity and functional importance of phytoplasma membrane proteins, in: Bertaccini, A., Oshima, K., Kube, M., Rao, G.P. (Eds.), Phytoplasmas: Plant Pathogenic Bacteria - III. Springer Singapore, Singapore, pp. 69-88. https://doi.org/10.1007/978-981-13-9632-8_5

Santos, D., Mingels, L., Vogel, E., Wang, L., Christiaens, O., Cappelle, K., Wynant, N., Gansemans, Y., Van Nieuwerburgh, F., Smagghe, G., Swevers, L., Vanden Broeck, J., 2019. Generation of virus- and dsRNA-derived siRNAs with species-dependent length in insects. Viruses 11, 738. https://doi.org/10.3390/v11080738

Sattar, S., Thompson, G.A., 2016. Small RNA regulators of plant-hemipteran interactions: micromanagers with versatile roles. Front. Plant Sci. 7. https://doi.org/10.3389/fpls.2016.01241

Suzuki, S., Oshima, K., Kakizawa, S., Arashida, R., Jung, H.-Y., Yamaji, Y., Nishigawa, H., Ugaki, M., Namba, S., 2006. Interaction between the membrane protein of a pathogen and insect microfilament complex determines insect-vector specificity. PNAS 103, 42524257. https://doi.org/10.1073/pnas.0508668103

Taning, C.N., Arpaia, S., Christiaens, O., Dietz- Pfeilstetter, A., Jones, H., Mezzetti, B., Sabbadini, S., Sorteberg, H., Sweet, J., Ventura, V., Smagghe, G., 2020. RNA- based biocontrol compounds: current status and perspectives to reach the market. Pest Manag. Sci. 76, 841-845. https://doi.org/10.1002/ps.5686

Tassetto, M., Kunitomi, M., Andino, R., 2017. Circulating immune cells mediate a systemic RNAi-based adaptive antiviral response in Drosophila. Cell 169, 314-325.e13. https://doi.org/10.1016/j.cell.2017.03.033

Taurino, F., Gnoni, A., 2018. Systematic review of plasma-membrane ecto-ATP synthase: a new player in health and disease. Exp. Mol. Pathol. 104, 59-70. https://doi.org/10.1016/j.yexmp.2017.12.006

Tomkins, M., Kliot, A., Marée, A.F., Hogenhout, S.A., 2018. A multi-layered mechanistic modelling approach to understand how effector genes extend beyond phytoplasma to modulate plant hosts, insect vectors and the environment. Curr. Opin. Plant Biol. 44, 39-48. https://doi.org/10.1016/j.pbi.2018.02.002

Vélez, A.M., Fishilevich, E., 2018. The mysteries of insect RNAi: a focus on dsRNA uptake and transport. Pestic. Biochem. Phys. 151, 25-31. https://doi.org/10.1016/j.pestbp.2018.08.005

Xu, Y., Huang, L., Wang, Z., Fu, S., Che, J., Qian, Y., Zhou, X., 2014. Identification of Himetobi $\mathrm{P}$ virus in the small brown planthopper by deep sequencing and assembly of virusderived small interfering RNAs. Virus Res. 179, 235-240. https://doi.org/10.1016/j.virusres.2013.11.004 
Xue, W. - H., Liu, Y. - L., Jiang, Y. - Q., He, S. - F., Wang, Q. - Q., Yang, Z. - N., Xu, H. - J., 2020. Molecular characterization of insulin- like peptides in the brown planthopper, Nilaparvata lugens (Hemiptera: Delphacidae). Insect Mol. Biol. 29, 309-319. https://doi.org/10.1111/imb.12636

Yu, X., Gowda, S., Killiny, N., 2017. Double-stranded RNA delivery through soaking mediates silencing of the muscle protein 20 and increases mortality to the Asian citrus psyllid, Diaphorina citri. Pest Manag. Sci. 73, 1846-1853. https://doi.org/10.1002/ps.4549

Zhu, K.Y., Palli, S.R., 2020. Mechanisms, applications, and challenges of insect RNA interference. Annu. Rev. Entomol. 65, 293-311. https://doi.org/10.1146/annurev-ento011019-025224

Zotti, M., dos Santos, E.A., Cagliari, D., Christiaens, O., Taning, C.N.T., Smagghe, G., 2018. RNA interference technology in crop protection against arthropod pests, pathogens and nematodes: RNA interference technology in crop protection against arthropod pests, pathogens and nematodes. Pest Manag. Sci. 74, 1239-1250. https://doi.org/10.1002/ps.4813 
bioRxiv preprint doi: https://doi.org/10.1101/2020.10.02.324350; this version posted October 2,2020 . The copyright holder for this preprint (which was not certified by peer review) is the author/funder, who has granted bioRxiv a license to display the preprint in perpetuity. It is made available under aCC-BY-NC-ND 4.0 International license.

Supplementary Table S1. List of primers and probes used in this work. T7 promoter sequence is in bold. Fluorophore reporter and quencher are in italic.

\begin{tabular}{|c|c|c|c|}
\hline Application & Primer name & $5^{\prime}-3^{\prime}$ Sequences & Target gene \\
\hline \multirow{4}{*}{ dsRNA synthesis } & Eva_T7ATPsynBetaf ${ }^{1}$ & TAATACGACTCACTATAGTACGGCCAGATGAACGAGCC & \multirow{2}{*}{ ATP synthase $\beta$} \\
\hline & Eva_T7ATPsynBetar ${ }^{1}$ & TAATACGACTCACTATAGGGACACCACGAGCAATGTTG & \\
\hline & T7GFPf ${ }^{1}$ & TAATACGACTCACTATAGCTTTTCACTGGAGTTGTCCC & \multirow{2}{*}{$\begin{array}{c}\text { Green Fluorescent } \\
\text { Protein (GFP) }\end{array}$} \\
\hline & T7GFPr 1 & TAATACGACTCACTATAGGTTTGTGTCCGAGAATGTTTC & \\
\hline \multirow{2}{*}{$\begin{array}{l}\text { qPCR (insect target } \\
\text { gene) }\end{array}$} & ATPßFw622 ${ }^{1}$ & CGCTTTACTCAGGCTGGTTC & \multirow{2}{*}{ ATP synthase $\beta$} \\
\hline & ATP $\beta R v 792{ }^{1}$ & GTCATCAGCTGGCACGTAGA & \\
\hline \multirow{4}{*}{$\begin{array}{c}\text { qPCR (insect } \\
\text { housekeeping gene) }\end{array}$} & EF1- $\alpha \_F 215^{1}$ & CCATCGACATTGCCCTGTGG & \multirow{2}{*}{ elongation factor- 10} \\
\hline & EF1- $\alpha \_R 325^{1}$ & CCTGTGAGGTTCCAGTGATCATG & \\
\hline & GST1_F257 ${ }^{1}$ & CCAAGGACCCCAAGAAGCGA & \multirow{2}{*}{$\begin{array}{l}\text { glutathione S- } \\
\text { transferase }\end{array}$} \\
\hline & GST1_R369 ${ }^{1}$ & TGGCGCTCCTCCAAACATCA & \\
\hline \multirow{3}{*}{$\begin{array}{c}\text { qPCR (phytoplasma } \\
\text { gene) }\end{array}$} & $\mathrm{CYS}_{2} \mathrm{Fw}^{2}$ & AGGTTGAACGGCCACATTG & \multirow{3}{*}{$\begin{array}{c}\text { Phytoplasma } \\
\text { 16Sr RNA }\end{array}$} \\
\hline & $\mathrm{CYS}_{2} \mathrm{Rv}^{2}$ & TTGCTCGGTCAGAGTTTCCTC & \\
\hline & CYS2Probe $^{2}$ & FAM-ACACGGCCCAAACTCCTACGGGA-TAMRA & \\
\hline \multirow{3}{*}{ qPCR (insect gene) } & GapFw632 ${ }^{3}$ & ATCCGTCGTCGACCTTACTG & \multirow{3}{*}{$\begin{array}{c}\text { glyceraldehyde-3- } \\
\text { phosphate } \\
\text { dehydrogenase } \\
\text { (GAPDH) }\end{array}$} \\
\hline & GapRv819 ${ }^{3}$ & GTAGCCCAGGATGCCCTTC & \\
\hline & GapEvProbe ${ }^{3}$ & HEX-ATATCAAGGCCAAGGTCAAGGAGGC-BHQ1 & \\
\hline
\end{tabular}

${ }^{1}$ Abbà, S.; Galetto, L.; Ripamonti, M.; Rossi, M.; Marzachì, C. RNA interference of muscle actin and ATP synthase beta increases mortality of the phytoplasma vector Euscelidius variegatus. Pest. Manag. Sci. 2019, 75, 1425-1434, doi:10.1002/ps.5263.

${ }^{2}$ Marzachí, C.; Bosco, D. Relative quantification of chrysanthemum yellows (16Sr I) phytoplasma in its plant and insect host using real-time polymerase chain reaction. Molecular Biotechnology 2005, 30, 117-128, doi:10.1385/MB:30:2:117.

${ }^{3}$ Ottati, S.; Persico, A.; Rossi, M.; Bosco, D.; Vallino, M.; Abbà, S.; Molinatto, G.; Palmano, S.; Balestrini, R.; Galetto, L.; et al. Biological characterization of Euscelidius variegatus iflavirus 1. Journal of Invertebrate Pathology 2020, 173, 107370, doi:10.1016/j.jip.2020.107370. 
bioRxiv preprint doi: https://doi.org/10.1101/2020.10.02.324350; this version posted October 2,2020 . The copyright holder for this preprint

(which was not certified by peer review) is the author/funder, who has granted bioRxiv a license to display the preprint in perpetuity. It is made available under aCC-BY-NC-ND 4.0 International license.

Supplementary Table S2. Mean normalized relative expression of ATP synthase $\beta$ transcript \pm standard error of the mean (SEM) measured in head/body/whole insect of Euscelidius variegatus samples at 15, 22 and 37 days post injection (dpi) of dsRNAs targeting ATP synthase $\beta$ or green fluorescent protein (GFP).

\begin{tabular}{|c|c|c|c|}
\hline Days post injection & Target of dsRNAs & Sample type & $\begin{array}{l}\text { Mean ATP synthase } \beta \\
\text { expression } \pm \text { SEM }(\mathrm{N})\end{array}$ \\
\hline \multirow{4}{*}{15} & \multirow{2}{*}{ ATP synthase $\beta$} & Head & $7.87 \mathrm{E}-03 \pm 1.86 \mathrm{E}-03(10)$ \\
\hline & & Body & $1.97 \mathrm{E}-02 \pm 9.03 \mathrm{E}-03(10)$ \\
\hline & \multirow{2}{*}{ GFP } & Head & $7.37 \mathrm{E}-01 \pm 1.06 \mathrm{E}-01(10)$ \\
\hline & & Body & $1.05 \pm 1.10 \mathrm{E}-01(9)$ \\
\hline \multirow{2}{*}{22} & ATP synthase $\beta$ & \multirow{2}{*}{ Whole body } & $2.08 \mathrm{E}-02 \pm 2.21 \mathrm{E}-03(92)$ \\
\hline & GFP & & $2.81 \pm 4.53 \mathrm{E}-01(79)$ \\
\hline \multirow{2}{*}{37} & ATP synthase $\beta$ & \multirow{2}{*}{ Whole body } & $2.25 \mathrm{E}-02 \pm 5.19 \mathrm{E}-03(14)$ \\
\hline & GFP & & $2.71 \pm 4.42 \mathrm{E}-01(14)$ \\
\hline
\end{tabular}




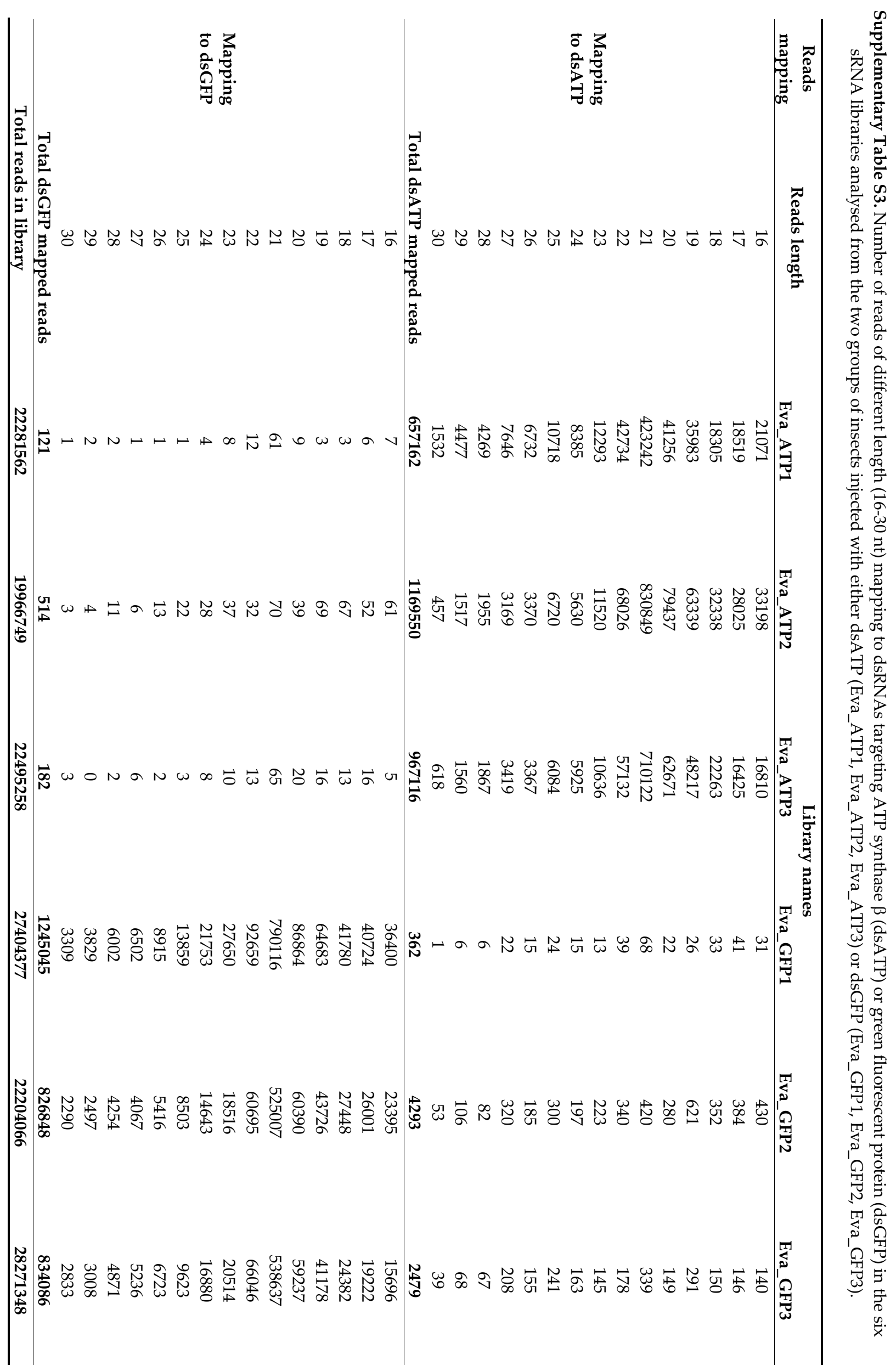


Supplementary Table S4. Mean intensity $/ \mathrm{mm}^{2}$ of Western blots (WB) bands depicted in Figure $4 \pm$ standard error of the mean (SEM) measured in Euscelidius variegatus insects, sampled at 15 days post injection of dsRNAs targeting ATP synthase $\beta$ or green fluorescent protein (GFP). This parameter is the sum of the intensity of each pixel calculated by Quantity One 1-D Analisys Software (Bio-Rad) included in the band boundary manually defined.

\begin{tabular}{ccc}
\hline Days post injection & Target of dsRNAs & $\begin{array}{c}\text { Mean intensity } / \mathbf{m m}^{2} \text { of } \\
\text { WB bands } \pm \text { SEM (N) }\end{array}$ \\
\hline \multirow{2}{*}{15} & ATP synthase $\beta$ & $2.37 \mathrm{E} 07 \pm 2.75 \mathrm{E} 06(6)$ \\
\cline { 2 - 3 } & GFP & $5.83 \mathrm{E} 07 \pm 7.17 \mathrm{E} 06(6)$ \\
\hline
\end{tabular}

Supplementary Table S5. Mean phytoplasma 16S RNAs/insect GAPDH transcript \pm standard error of the mean (SEM) measured in Euscelidius variegatus insects, sampled at 22 days post injection of dsRNAs targeting ATP synthase $\beta$ or green fluorescent protein (GFP) and at 7 days post acquisition of chrysanthemum yellows (CYp) or Flavescence dorée (FDp) phytoplasmas, as detailed in methodology depicted in Figure 1.

\begin{tabular}{|c|c|c|}
\hline $\begin{array}{l}\text { Target of } \\
\text { dsRNAs }\end{array}$ & $\begin{array}{l}\text { Phytoplasma acquired } \\
\text { post dsRNA injection }\end{array}$ & $\begin{array}{l}\text { Mean phytoplasma } \\
\text { quantity } \pm \text { SEM (N) }\end{array}$ \\
\hline ATP synthase $\beta$ & \multirow{2}{*}{ CYp } & $6.94 \mathrm{E}-03 \pm 2.12 \mathrm{E}-03(42)$ \\
\hline GFP & & $3.74 \mathrm{E}-02 \pm 1.03 \mathrm{E}-02(43)$ \\
\hline ATP synthase $\beta$ & \multirow{2}{*}{ FDp } & $2.49 \mathrm{E}-02 \pm 1.00 \mathrm{E}-02(39)$ \\
\hline GFP & & $1.01 \mathrm{E}-01 \pm 2.68 \mathrm{E}-02(36)$ \\
\hline
\end{tabular}


bioRxiv preprint doi: https://doi.org/10.1101/2020.10.02.324350; this version posted October 2, 2020. The copyright holder for this preprint (which was not certified by peer review) is the author/funder, who has granted bioRxiv a license to display the preprint in perpetuity. It is made available under aCC-BY-NC-ND 4.0 International license.
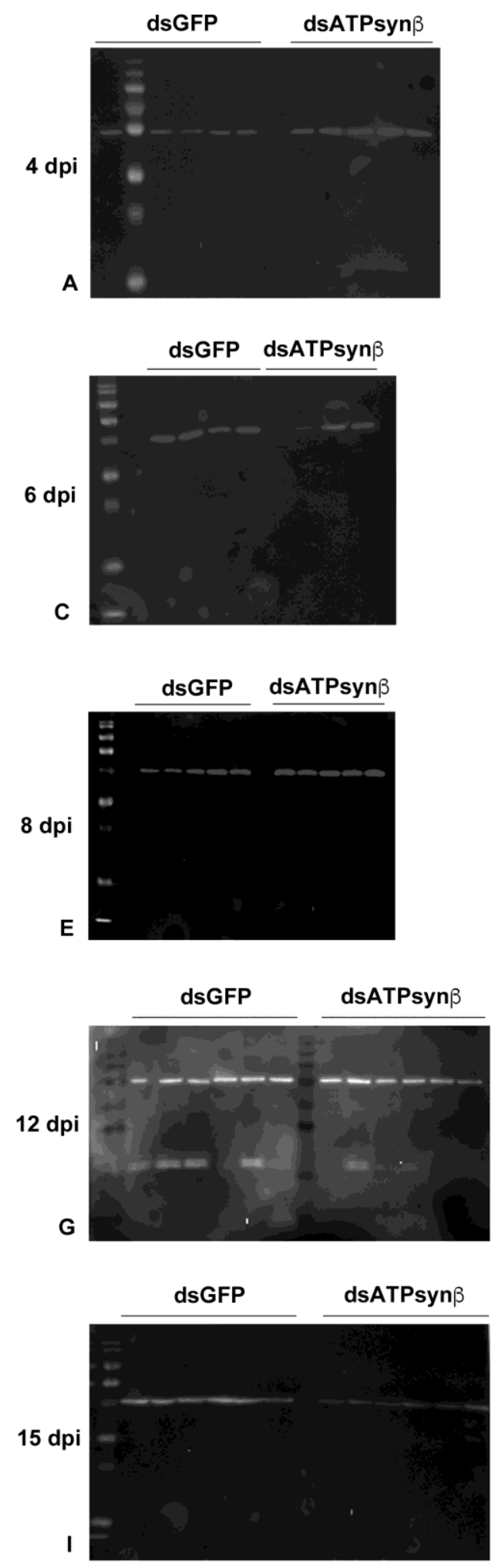
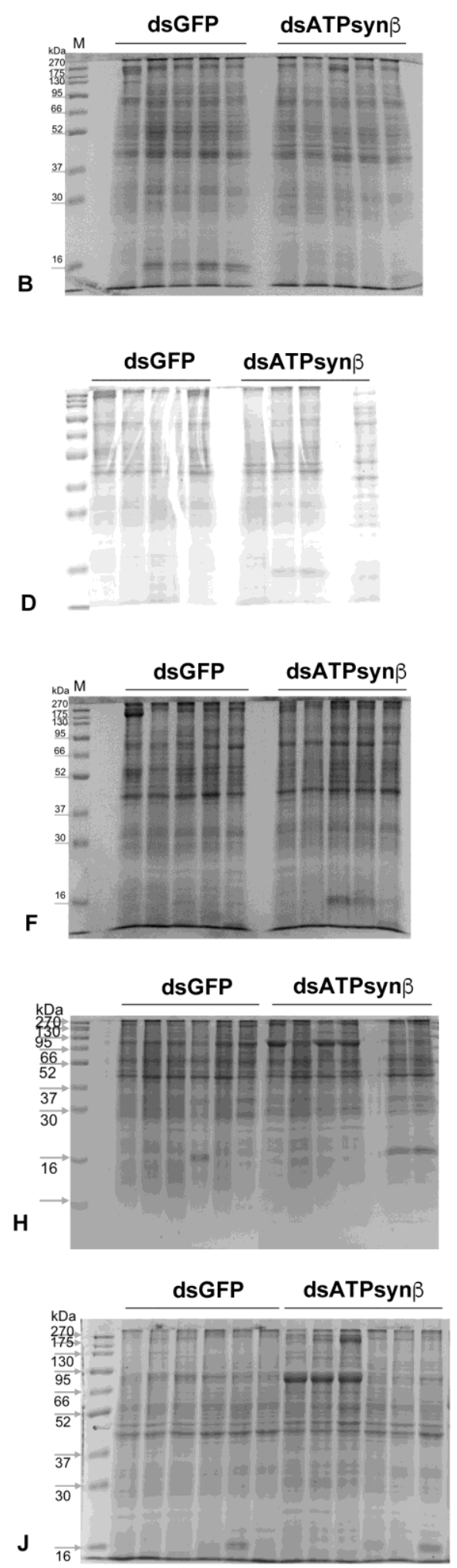

Supplementary Figure S1. Full lenght images of Western blots (WB) (left column, A, C, E, G, I) depicted in Figure 4, developed with anti-ATP synthase $\beta$ antibody, and corresponding Coomassie stained SDS-polyacrylamide gels (right column, B, D, F, H, J), run in parallel with WB on the same Euscelidius variegatus insect samples (one insect sample per single lane), analysed at $4,6,8,12,15$ days post injection (dpi) of dsRNAs targeting ATP synthase $\beta$ $(\mathrm{dsATPsyn} \beta)$ or green fluorescent protein (dsGFP). 